Undas Vol 12. , Nomor 1, Juni 2016 : 17--26

\title{
FUNGSI DAN STRATEGI TINDAK KOMPETITIF DALAM TEGUR SAPA BANJAR
}

\author{
The Function and the Strategy Follow Competitive In the Greet In Banjar Language
}

\author{
Rissari Yayuk \\ Balai Bahasa Kalimantan Selatan \\ Jalan Jenderal Ahmad Yani Km 32,2, Loktabat, Banjarbaru 70712 Kalimantan Selatan \\ Telepon (0511) 4772641, Pos-el: yrissariyayuk@yahoo.co.id
}

\begin{abstract}
Abstrak: Penelitian ini membahas tentang fungsi dan strategi tindak kompetitif dalam tegur sapa Bahasa Banjar. Masalah yang dibahas meliputi 1) bagaimana fungsi tindak kompetitif dalam tegur sapa bahasa Banjar. 2) strategi kompetitif apa saja yang digunakan dalam tegur sapa bahasa Banjar. Tujuan penelitian adalah untuk mendeskripsikan 1) fungsi tindak kompetitif dalam tegur sapa bahasa Banjar. 2) strategi kompetitif yang digunakan dalam tegur sapa bahasa Banjar. Teknik yang digunakan dalam pengambilan data adalah teknik lapangan, rekam dan dokumentasi. Teknik ini digunakan untuk mendapatkan data lisan dan tertulis sebagai pendukung kajian. Data diambil dari tuturan langsung masyarakat Banjar di Kelurahan Sekumpul, Desa Sungai Kacang, pada Bulan Januari 2016 s.d Maret 2016. Berdasarkan hasil penelitian, fungsi tindak tutur kompetitif dala tegur sapa yang terdapat dalam kebertergursapaan Banjar meliputi kompetitif menilai, melarang, dan menyarankan. Strategi yang digunakan terdiri atas strategi langsung dan tidak langsung.
\end{abstract}

Kata kunci: Fungsi, kompetitif, Banjar

\begin{abstract}
The Research study entitled function and the strategy competitive the greet in Banjar language the problem which are discuss in this study 1) how the fungction of the act competitive the greet in Banjar language. 2) any competitive strategy used in the greet of Banjar language. The aimis of this study are describe 1) The fungction of the act competitive the greet in Banjar language. 2) competitive strategy used in the greet of Banjar language. This study is categorized in descriptive qualitative. The data are gained from recording, written, and documentation from Januari until March 2015. This technique is used to obtain the data of oral and ewitten as a supporter of the study. Data taken from the direct speech in the village of Banjar people Sekumpul, Sungai Kacang. The result show that the implementation of the function of act greet competitive the greting exchanged contained in Banjar. The greeting exchanged include competitive judge, prohibit, and advise. The strategy used consists of direct and undirect strategy.
\end{abstract}

Key words: Function, competitive, Banjar

\section{PENDAHULUAN}

Masyarakat Banjar merupakan penutur bahasa Banjar yang mendominasi di Provinsi Kalimantan Selatan. Bahasa Banjar menjadi bahasa perhubungan dalam kehidupan seharihari. Masyarakat Banjar menjalin komunikasi dalam kehidupan sosial, sebagai penutur bahasa Banjar melakukan ragam tindak berbahasa yang diwujudkan dalam bentuk ujaran yang santun atau sopan melalui kata, frase, dan kalimat. Ujaran-ujaran ini dilakukan dengan tujuan tertentu pula, seperti untuk menciptakan suasana keakraban yang erat antarpenutur bahasa di tengah masyarakat. Salah satu tindak yang mesti dilakukan agar 
keakraban dan keharmonisan antarwarga terwujud melalui rarawaan 'tegur sapa'.

Tegur sapa dalam kontak kehidupan sosial masyarakat Banjar memperlihatkan berfungsinya bahasa secara fatik yang memiliki tujuan sosial, yaitu fungsi bahasa sebagai sarana pemelihara hubungan yang baik dalam kehidupan sosial. Bahasa yang baik antara lain bercirikan bahasa yang santun atau beretika ketika dituturkan di tengah masyarakat atau kehidupan sosial.

Chaer (2010:104-105) menjelaskan tegur sapa adalah ujaran atau tuturan santun yang kita gunakan untuk menyapa mitra tutur saat bertemu, berpapasan, atau melewatinya di suatu tempat. Ujaran ini bisa ini bisa berupa kata, frase, dan kalimat, bahkan narasi. Ujaran biasanya disertai senyum dan anggukan kepala. Tegur sapa antarpenutur dan mitra tutur ini akan menciptakan situasi yang harmonis dan menyenangkan. Misalnya penutur melewati mitra tutur yang sedang duduk, alangkah baiknya memanggil namanya seraya berujar permisi. Hal ini menunjukkan penutur menghargai dan menghormati mitra tutur, dan penutur melakukan tegur sapa meminta izin.

Ujaran dalam tegur sapa yang memiliki tujuan sosial ini mengandung tindak tutur yang beragam. Yule ( dalam Jumadi, 2006: 82), menyatakan bahwa "Tindak tutur merupakan tindakan-tindakan yang ditampilkan lewat tuturan, misalnya usaha seseorang dalam mengungkapkan diri mereka. Mereka tidak hanya menghasilkan tuturan yang mengandung kata-kata saja, tetapi mereka memperlihatkan tindakan-tindakan melalui tuturan itu". Maksudnya sudah jelas bahwa jika seseorang ingin mengungkapkan sesuatu maka ia akan menunjukkannya melalui tindakan yang disampaikan dengan ujaran.

Sementara itu, Leech (dalam Baryadi, 2012: 31) menyatakan salah satu tindak tutur berdasarkan kesesuaian dengan tujuan sosial adalah tindak tutur kompetitif. Rahardi (2005: 17) menyatakan bahwa setiap tindak tutur berbahasa memiliki bentuk dan fungsi masingmasing.

Penelitian ini mengangkat judul fungsi dan strategi tindak kompetitif dalam tegur sapa Banjar. Masalah yang dibahas meliputi 1) bagaimana fungsi tindak kompetitif dalam tegur sapa Banjar, 2) strategi kompetitif apa saja yang digunakan dalam tegur sapa Banjar. Tujuan penelitian ialah untuk mendeskripsikan 1) fungsi tindak kompetitif dalam tegur sapa Banjar, 2) strategi kompetitif yang digunakan dalam tegur sapa Banjar.

Penelitian yang berkaitan dengan tindak tutur berbahasa sudah pernah dilakukan, penelitian tersebut tersebut yaitu Kesantunan Direktif Bahasa Banjar oleh Ahmad Zaini (2010) dan Musdalifah pada tahun 2010 dengan judul Kesantunan Meminta dalam Bahasa Banjar dan pada tahun 2012 Rissari Yayuk meneliti "Maksim Kesopanan dalam Tuturan Penumpang dan Tukang Ojek di Pasar Hanyar Kota Banjarmasin". Pada penelitian Zaini (2010) dan Musdalifah (2010) mengupas tentang realisasi penerapan kesantunan dalam bahasa Banjar. Penelitian Yayuk (2012) mengkaii tentang pelaksanaan maksim kesantunan pada tuturan penumpang dan tukang ojek di Pasar Hanyar. Penelitianpenelitian tersebut berfokus pada kesantunan dalam tindak tutur berbahasa tidak membahas mengenai tindak tutur kompetitif dalam tegur sapa Banjar.

Berdasarkan informasi sebelumnya, penelitian dengan judul tindak dan modus kompetitif dalam tegur sapa berbahasa Banjar ini sepengetahuan peneliti belum pernah diteliti. Di samping itu, penelitian ini penting dilakukan sebagai upaya pendokumentasian tindak ujar bahasa Banjar yang selama ini masih sedikit dikaji. Hasil penelitian ini 
diharapkan akan memberi manfaat bagi penelitian lainnya yang berdasarkan teori pragmatik.

\section{KERANGKA TEORI}

\section{Pragmatik}

Kridalaksana (1993: 177) menyatakan bahwa pragmatik (pragmatics) adalah ilmu yang menyelidiki pertuturan, konteksnya dan maknanya. Selain itu Tarigan (1986: 25) menyatakan bahwa pragmatik adalah suatu telaah makna dalam hubungannya dengan aneka situasi ujaran. Pragmatik diperlukan dalam menganalisis makna yang dipertuturkan oleh penutur disesuaikan dengan situasi ujar. Kridalaksana (1993: 177) yang menyatakan bahwa pragmatik (pragmatics) adalah ilmu yang menyelidiki tindak tutur berdasarkan konteksnya dan maknanya.

\section{Tindak Tutur}

Berkaitan dengan tindak tutur Richards (Suyono, 1990: 5) berpendapat mengenai tindak tutur sebagai the things we actually do when we speak' sesuatu yang benar-benar kita lakukan ketika bertutur' atau the minimal unit of speaking which can be said to have functioan 'satuan terkecil dari unit tuturan yang dapat dikatakan memiliki fungsi'. Chaer dan Agustina (2005: 64) lebih mengkhususkan tindak tutur sebagai gejala individual, bersifat psikologis, dan keberlangsunganya ditentukan oleh kemampuan bahasa si penutur dalam menghadapi situasi tertentu. Leech dalam Jumadi (2005: 115) menyebutkan tindak tutur atau speech act merupakan suatu tindakan yang diungkapkan melalui bahasa yang disertai dengan gerak dan sikap anggota badan untuk mendukung maksud pembicara. Tindak tutur ditentukan oleh adanya beberapa aspek situasi ujar , antara lain (1) yang menyapa (penutur) dan yang disapa (petutur); (2) latar belakang; (3) tujuan sebuah tuturan; (4) bentuk tindak kegiatan; (5) produk tindak verbal.

Aktivitas bertutur dengan segala aspeknya di atas oleh Keith Alan (dalam Rahardi, 2009: 22) disebutnya dengan kegiatan yang berdemensi sosial. Sebagai sebuah proses komunikasi , proses bertutur ini akan berjalan dengan baik semua peserta tutur telibat aktif. Karena itu perlu kerjasama yang kuat antar peserta tutur salah satunya adalah dengan berperilaku sopan atau santun.

\section{Tindak Tutur Kompetitif}

Ibrahim (1991: 27) menyatakankan menurut Searle, ada lima bentuk tindak tutur yang dilakukan orang sewaktu memproduksi ujaran dilihat dari fungsi ilokusinya. Pembagian didasarkan bentuk tuturan dan kategori tindakan yang dilakukan oleh seseorang, meliputi tindak tutur direktif, tindak tutur asertif, komisif, ekspresif, dan deklaratif.

Sementara itu, Leech (dalam Baryadi, 2012: 31) menyatakan salah satu bentuk tindak tutur adalah kompetitif. Tindak tutur kompetitif adalah tindak tutur yang bertujuan sosial. Baryadi (2012:31) menyatakan yang dimaksud dengan tujuan sosial adalah tindak tutur untuk menciptakan hubungan yang harmonis atau tidak antara penutur dan mitra tutur. Berikut penjelasan mengenai tindak tutur kompetitif yang bertujuan sosial sebagaimana yang dimaksud Leech.

\section{Fungsi Tindak Tutur Kompetitif}

Tindak tutur kompetitif adalah tindak tutur yang bersaing untuk tujuan sosial, seperti berfungsi untuk menilai, memerintah, dan melarang. Biasanya tindak tutur ini memiliki maksud agar mitra tutur mengakui apa yang dikatakan oleh penutur. Penutur berharap mitra tutur akan melakukan tindakan 
pengiyaan atau pembenaran baik melalui perkataan atau perilaku verbal lainnya atas apa yang dituturkannya melalui tindak kompetitifnya tersebut.Tindak tutur ini biasanya memiliki penanda atau modalitas seperti untuk menyatakan perbandingan atau penilaian dari segi makna ujaran. Modalitas ayo untuk kompetitif perintah. Modalitas jangan untuk kompetitif melarang, modalitas sebaiknya untuk kompetitif nasihat, dan modalitas tidak untuk kompetitif menyangkal.

\section{Strategi Tindak Kompetitif}

Dalam sebuah komunikasi, penggunaan strategi tindak tutur oleh penutur dapat dilakukan dengan secara langsung dan tidak langsung. Penggunaan strategi ini agar mencapai tujuan komunikasi.

\section{Strategi Tindak Tutur Kompetitif Langsung}

Strategi langsung adalah strategi yang secara langsung mengungkapkan maksud tuturan. Melalui strategi ini penutur mengharapkan mitra tutur dapat memahami tuturan secara efektif. (Karim, 2011:168-170).

Gunawan (1993: 168) menyatakan derajat kelangsungan suatu tuturan dapat diukur berdasarkan daya pragmatisnya. Tuturan yang memiliki daya pragmatis paling jelas merupakan tuturan yang disampaikan secara langsung.

\section{Strategi Tindak Tutur Kompetitif Tidak langsung}

Karim (2011: 168) menyatakan strategi tidak langsung adalah strategi dengan tuturan yang disampaikan dengan cara lain untuk mengungkapkan suatu maksud. Arti lain adalah sebuah strategi bertutur yang secara tidak langsung mengungkapkan maksud tuturan Rohmadi (2004: 35) menyatakan tindak tidak langsung adalah tindak tutur yang diutarakan dengan modus kalimat yang tidak sesuai dengan maksud yang diutarakan..

\section{METODE PENELITIAN}

Metode yang digunakan dalam penelitian ini adalah metode deskriptif kualitatif analitis. Metode ini dipilih karena penelitian ini dilakukan untuk mendapatkan gambaran secara alamiah mengenai tindak kompetitif pada masyarakat Banjar. Data yang dikumpulkan berbentuk deskripsi percakapan penutur bahasa Banjar dalam ragam situasi dan kondisi. Pengumpulan data dilakukan dengan cara pengamatan dan perekaman. Pengamatan dan perekaman ini dilakukan untuk membuat catatan atau dokumentasi dari lapangan secara langsung atas apa yang dilihat, dialami, dan dipikirkan dari data primer. Data di ambil dari tuturan lisan masyarakat di Kelurahan Sekumpul, Desa Sungai Kacang.Data sekunder dalam tulisan ini adalah literatur yang diperoleh secara tidak langsung untuk mendukung penulisan pada kajian ini melalui dokumen atau catatan yang berhubungan dengan bahasa Banjar.

Teknik yang digunakan dalam tulisan ini adalah pengambilan sampel purposive sampling, yaitu teknik pengambilan sampel sumber data dengan pertimbangan tertentu (Sugiyono, 2009: 300). Penetapan sampel tidak didasarkan keterwakilan dalam hal jumlah responden (besar sampel), tetapi berdasarkan kualitas atau ciri-ciri responden yang ingin diwakili.

Berdasarkan metode dan teknik di atas, penulis menggunakan tiga langkah kerja, yaitu tahap pengumpulan data, pengolahan data, dan tahap penyajian 
hasil analisis data, hal ini sesuai pula dengan yang dimaksudkan Sudaryanto (2003: 57). Data yang telah dikumpulkan selanjutnya diperiksa secara selektif berdasarkan permasalahan yang ada, data terpilih ini dianalisis disesuaikan dengan teori pragmatik, dan disajikan dengan metode informal atau kata-kata biasa.

Populasi penelitian ini adalah masyarakat Banjar yang berlokasi di Kelurahan Sekumpul, Kabupaten Banjar di Kalimantan Selatan. Penetapan sampel tidak didasarkan keterwakilan dalam hal jumlah responden (besar sampel), tetapi berdasarkan kualitas atau ciri-ciri responden yang ingin diwakili.

\section{ANALISIS DAN PEMBAHASAN}

\section{Fungsi Tindak Kompetitif}

Berdasarkan hasil penelitian, fungsi tindak tutur kompetitif yang terdapat dalam kebertergursapaan Banjar meliputi

\section{a. Menilai}

Pada tindak kompetitif yang berfungsi menilai ini biasanya berkaitan dengan cara pandang penutur dalam melihat, mendengar, atau merasakan sesuatu yang berhubungan dengan mitra tutur. Penilaian yang dimaksudkan seperti, membandingkan, tentang baik buruknya, bagus tidaknya, tepat tidaknya. Data berikut menunjukkan gejala itu.

\section{Data [1]}

P: Umaai pas dicat pinda bahanyarlah rumah ikam.

'Aduh setelah di beri cat terlihat seperti baru ya rumah kamu'. (1)
MT: Dasar bujur Cilai, asa nyaman jua nah ulun mangganai.

'Memang benar bi, terasa enak juga saya mendiami'. (2)

Konteks tuturan:

Seorang tetangga baru mencat rumah lama yang baru dibeli dan akan ditempati. Penutur merasa sedikit terkejut melihat rumah yang berada di dekat rumahnya tersebut terlihat bagus dan baru ketika di cat ulang.

Data [1], memiliki konteks seorang tetangga baru mencat rumah lama yang baru dibeli dan akan ditempatinya. Penutur merasa sedikit terkejut melihat rumah yang berada di dekat rumahnya tersebut terlihat bagus dan baru ketika di cat ulang. Sementara mereka baru saling mengenal. Konteks ini menjadi alasan bagi penutur untuk bertegur sapa.

Akhirnya, melalui tuturan [1], penutur mencoba mempererat hubungan yang harmonis dengan tetangga barunya tersebut. Tegur sapa yang dia lontarkan pun menjadi penghubung komunikasi antara penutur dengan mitra tutur. Penutur mengujarkan tegur sapanya yang kirakira akan diiyakan oleh mitra tutur dan menyenang hati mitra tutur. Dia memberikan komentar Umaai pas dicat pinda bahanyarlah rumah ikam' (Aduh setelah diberi cat terlihat baru ya rumah kamu').

Ujaran (1) memiliki penanda kompetiti penilaian seperti dalam tegur sapa pujian. Sebagai sebuah tindak kompetitif penilaian, penutur berhasil merealisasikan maksud agar mitra tutur mengakui apa yang dikatakan oleh penutur. Harapan penutur agar mitra tutur akan melakukan tindakan 
pengiyaan atau pembenaran baik melalui perkataan atau perilaku verbal lainnya atas apa yang dituturkannya melalui tindak kompetitifnya tersebut menjadi terlaksana. Mitra tutur melakukan ujaran balik yang memiliki makna persetujuan dengan apa yang diujarkan penutur dengan frase dasar bujur 'memang benar'. Mitra tutur membalas ujaran kompetitifnya yang berwujud penilaian ini, Dasar bujur Cilai, asa nyaman jua nah ulun mangganai ('Memang benar bi, terasa enak juga saya mendiami').

\section{b. Melarang}

Tindak kompetitif yang berfungsi melarang ini biasanya berhubungan dengan keinginan penuttur agar mitra tutur tidak melakukan sesuatu sebagaimana yang diujarkan.Data berikut menunjukkan gejala itu.

\section{Data [2]}

P: Jangan balalajuan lah, kaina rabah. 'Jangan berlomba cepat-cepatan ya, nanti jatuh'(1)

MT: Kada kami baramian haja. 'Tidak, kami cuma main-main saja' (2)

Konteks:

Penutur melihat sekelompok anakanak sedang menaiki sepeda saling berlomba cepat di jalan desa.

Data [2] memiliki konteks penutur melihat sekelompok anak-anak sedang menaiki sepeda saling berlomba cepat di jalan desa.Rasa khawatir akan terjadi sesuatu terhadap mitra tutur yang hanya sekelompok anak-anak tersebut menyebabkan penutur berujar pada tuturan (1) Jangan balalajuan lah,kaina rabah. ('Jangan berlomba bercepat- cepatan ya, nanti jatuh'). Harapannya mitra tutur akan memahami apa yang dia ujarkan dan mengikuti apa yang dia peringatkan. Namun, ternyata harapan penutur tidak mendapat balasan yang baik. Mitra tutur malah mengelak kalau mereka tidak sedang berlomba. Kada kami baramian haja ('Tidak, kami cuma main-main saja').

Ujaran pada data [2] ini memiliki penanda kompetitif melarang jangan dalam tegur sapa perhatian pada ujaran Jangan balalajuan lah, kaina rabah. 'Jangan berlomba bercepat-cepatan ya, nanti jatuh'. Penutur jelas melakukan pertentangan dengan keinginan mitra tutur, namun demi tujuan sosial, yaitu tidak menghendaki mitra tutur mengalami sesuatu maka dia melakukan tindak tutur kompetitif.

\section{c. Menyarankan}

Tindak kompetitif bahasa Banjar yang berfungsi menyarankan ini biasanya ditandai modalitas baiknya atau sabaiknya 'sebaiknya', handaknya 'hendaknya', atau kaya apa amun' bagaimana kalau'.Penutur memiliki keinginan agar mitra tutur mendengarkan dan mengikuti apa yang dia sarankan. Tindak tutur ini memiliki maksud agar mitra tutur mengakui apa yang dikatakan oleh penutur adalah sebuah kebenaran. Hal ini sebagai wujud kepedulian sosial terhadap mitra tutur.

\footnotetext{
Data [3]

P: Baiknya ikam pariksa businya, kalu rigat.

'Sebaiknya kamu periksa businya terlebih dahulu, siapa tahu $\operatorname{kotor}^{\prime}(1)$
} 
MT: Oh inggih, kada ingat ulun, businya lawas pang kada suah ulun lihati, makasih.

‘Oh iya , lupa saya, businya lama sudah tidak saya periksa. Makasih' (2)

Konteks:

Penutur melihat mitra tutur yang mau berangkat bekerja sedang berusaha keras menghidupi mesin kendaraannya yang membandel.

Data [3] pada tuturan (1) menggunakan tindak tutur kompetitif menyarankan sebaiknya dalam tegur sapa mengingatkan Baiknya ikam pariksa businya, kalu rigat ('Sebaiknya kamu periksa businya terlebih dahulu, siapa tahu kotor') (1). Ketika itu penutur baru keluar dari rumahnya. Tiba-tiba melihat tetangganya yang akan berangat ke kantor begitu keras berusaha menghidupi kendaraan. Penutur merasa kasihan, lalu dia memberi nasihat agar mitra tutur itu memeriksa busi kendaraannya. Nasihatnya ini dituruti oleh mitra tutur. Mitra tutur bahkan mengucapkan terimaksih atas nasihat penutur tersebut. Oh inggih, kada ingat ulun, businya lawas pang kada suah ulun lihati, makasih ( 'Oh iya , lupa saya, businya lama sudah tidak saya periksa. Makasih') (2)

Tindak tutur kompetitif menyarankan bahasa Banjar yang terdapat pada data [3] sesuai dengan tindak tutur berbahasa sebagaimana yang dimaksudkan Leech dalam (Baryadi 2012:31) yakni, tindak tutur ini memiliki maksud agar mitra tutur mengakui apa yang dikatakan oleh penutur. Penutur berharap mitra tutur akan melakukan tindakan pengiyaan atau pembenaran baik melalui perkataan atau perilaku verbal lainnya atas apa yang dituturkannya melalui tindak kompetitifnya tersebut. Tindak tutur ini biasanya memiliki penanda baiknya atau sebaiknya.

\section{Strategi Tindak Kompetitif}

Dalam sebuah komunikasi, penggunaan strategi tindak tutur oleh penutur dapat dilakukan dengan secara langsung dan tidak langsung. Penggunaan strategi ini agar mencapai tujuan komunikasi.

\section{a. Strategi Tindak Tutur Kompetitif Langsung}

Penggunaan strategi ini dapat dilihat pada data [1] dan [2] . Pertama, data [1] pada tuturan (1) : Umaai pas dicat pinda bahanyarlah rumah ikam 'Aduh setelah di beri cat terlihat seperti baru ya rumah kamu'. Menyatakan makna dan maksud yang sama. Yaitu penutur langsung menyatakan bahwa rumah yang baru dibeli tetangganya tersebut kelihatannya baru karena sudah dicat. Tindak kompetitif menilai dengan penanda pinda'seperti' yang dilakukan penutur merupakan anggapan penutur atas apa yang sudah dan sedang dilihatnya ketika itu. Penutur berharap mitra tutur akan mengakui pernyataannya tersebut. Jawaban mitra tutur pada tuturan [2] Dasar bujur Cilai, asa nyaman jua nah ulun mangganai ('Memang benar bi, terasa enak juga saya mendiami' )memenuhi keinginan penutur. Penutur mengakui kalau rumahnya memang terlihat baru setelah dicat dan dia merasa lebih nyaman dengan keadaan tersebut.

Kedua. Data [2] pada tuturan (1), Jangan balalajuan lah, kaina rabah. ('Jangan berlomba bercepat-cepatan ya, nanti 
jatuh'). Penutur langsung melakukan tindak kompetitif melarang dengan penanda langsung jangan. Ujarannya sangat jelas makna dan maksudnya, yakni melarang mitra tutur agar jangan berlomba saat mengendarai sepeda mereka. Penutur melakukan larangan ini karena dia tidak ingin terjadi sesuatu dengan mitra tutur yang terdiri atas anak-anak tetangganya sendiri.

Meskipun kemudian, ujaran kompetitif yang dilakukan penutur secara langsung ini begitu jelas makna dan maksudnya, akan tetapi mitra tutur ternyata tidak begitu saja menerima larangan ini. Mereka malah mengelak dengan berujar Kada kami baramian haja 'Tidak, kami cuma main-main saja'.Ujaran mitra tutur ini sebenarnya mematahkan larangan mitra tutur yang memiliki tujuan baik. Hal ini sebagi bukti bahwa tindak kompetitif melarang dengan tujuan sosial dalam kehidupan masyarakat Banjar tidak selamanya direspon sesuai keinginan penutur.

Tindak ujaran kompetitif yang dilakukan penutur pada data [1] dan [2] sesuai dengan apa yang dimaksudkan Gunawan (1993:168) yang menyatakan derajat kelangsungan suatu tuturan dapat diukur berdasarkan daya pragmatisnya. Tuturan yang memiliki daya pragmatis paling jelas merupakan tuturan yang disampaikan secara langsung.

\section{b. Strategi Tindak Tutur Kompetitif Tidak Langsung}

Data [3] pada tuturan (1) merupakan dua contoh penggunaan tindak tutur kompetitif tidak langsung. Baiknya ikam pariksa businya, kalu rigat 'Sebaiknya kamu periksa businya terlebih dahulu, siapa tahu kotor'. Penutur menggunakan penanda tindak kompetitif memberi saran secara tidak langsung sebaiknya. Penutur untuk memperhalus ujaran kompetitif sarannya menggunakan kata yang sekiranya mitra tutur tidak merasa diberi perintah. Penutur tidak menggunakan ujaran ikam pariksa pang businya, kalu rigat 'kamu periksa dong businya terlebih dahulu, siapa tahu kotor'. Apabila penutur menggunakan ujaran seperti ini tentu menyatakan ujaran langsung menyarankan, sebab ada penanda perintah saran berupa modalitas penegas pang 'dong'. Kesantunan berbahasa yang diujarkan penutur ini membuat mitra tutur menjawab santun bahkan tampak gembira dia balas berujar Oh inggih, kada ingat ulun, businya lawas pang kada suah ulun lihati, makasih ('Oh iya, lupa saya, businya lama sudah tidak saya periksa. Makasih' ) (2).

Ujaran kompetitif pada data data [3] ini menggunakan strategi tidak langsung sebagaimana yang dkatakan Karim. Karim (2011:168) menyatakan strategi tidak langsung adalah strategi dengan tuturan yang disampaikan dengan cara lain untuk mengungkapkan suatu maksud. Arti lain adalah sebuah strategi bertutur yang secara tidak langsung mengungkapkan maksud tuturan.

\section{PENUTUP}

Fungsi tindak tutur kompetitif dalam tegur sapa yang terdapat dalam kebertergursapaan Banjar meliputi kompetitif menilai, melarang, dan menyarankan. Untuk kompetitif menilai 
menggunakan penanda pinda 'seperti', melarang penandanya jangan 'jangan, dan menyarankan baiknya 'sebaiknya'. Strategi yang digunakan terdiri atas strategi langsung dan tidak langsung. Ujaran kompetitif yang memiliki tujuan sosial yang diwujudkan dalam ragam konteks komunikasi di tengah kehidupan masyarakat Banjar ini tidak selamanya mendapat respon yang bersifat sesuai dengan harapan dan keinginan penutur. Mitra tutur dapat menanggapi dengan santun atau sebaliknya bisa menyangkal bahkan tidak peduli.

Akhirnya, materi penelitian ini dapat digunakan sebagai salah satu referensi bagi peneliti bahasa daerah berikutnya yang mengambil teori yang sama atau berbeda.

\section{DAFTAR PUSTAKA}

Baryadi, I.Praptomo. 2012. Bahasa, Kekuasaan, dan Kekerasan. Jogyakarta. Sanata Darma.

Chaer, Abdul. 2010. Sosiolinguistik Perkenalan Awal. Jakarta: Rineka Cipta.

Chaer, Abdul dan Leonie Agustina. 1995. Sosiolinguistik: pengenalan awal. Jakarta: Balai Pustaka.

Chaer, Abdul dan Leonie Agustina. 2005. Sosiolinguistik: pengenalan awal. Jakarta: Balai Pustaka.

Gunawan, Asim. 1993. Kesantunan Negatif di Kalangan Dwibahasawan Indonesia-Jawa di Jakarta; Kajian Sosiopragmatik; dalam PELBA 7. Penyunting Bambang Kaswanti Purwo. Yogyakarta:Kanisius.

Ibrahim, Abdul Syukur. 1991. Kajian Tindak Tutur. Surabaya: Usaha Nasional.

Jumadi. 2005. Representasi Kekuasaan. Jakarta. Pusat Bahasa.

Karim, Ali. 2011. Tindak perintah dalam Wacana Kelas:Kajian Strategi Bertutur dalam Jurnal Widyaparwa 1: 167-174. Yogyakarta:Balai Bahasa Yogyakarta.

Kridalaksana, Harimurti. 1993. Pragmatik. Jakarta: Gramedia.

Musdalifah (Ed). 2010. Kesantunan Meminta dalam Bahasa Banjar.Undas. Banjarbaru:Balai Bahasa Banjarmasin

Rahardi R. Kunjana. 2005. Pragmatik. Jakarta:Erlangga

Rahardi R. Kunjana. 2009. Pragmatik. Jakarta:Erlangga

Rohmadi, Muhammad. 2004. Pragmatik Teori dan Analisis. Jogya:Lingkar Media Jogja

Sudaryanto. 2003. Metode dan Aneka Teknik Analisis Bahasa: Pengantar Penelitian Wahana Kebudayaan secara Linguistis. Yogyakarta: Duta Wacana University Press. 
Fungsi dan Strategi Tindak Kompetitif dalam Tegur Sapa Banjar (Rissari Yayuk)

Sugiyono. 2009. Metode Penelitian. Bandung: Alfabeta

Suyono. 1990. Pragmatik: Dasar-Dasar dan Pengajaran. Malang: YA3.

Tarigan, Guntur. 1986. Pragmatik dan Pengajarannya. Bandung:Angkasa

Tarigan, Henry Guntur. 1986. Pragmatik dan Pengajarannya. Bandung:Penerbit Angkasa

Yayuk, Rissari. 2012." Pelanggaran Prinsip Kesantunan Supir Angkutan Umum Jurusan

Martapura" . Prosiding Seminar Kebahasaan dan Kesastraan Yokyakarta .Yoyakarta: Balai Bahasa Yogyakarta

Yule, George. 1996. Pragmatics. Terjemahan Jumadi. 2006. Pragmatik. Banjarmasin: Unlam.

Zaini, Ahmad(Ed). 2010. Kesantunan Direktif Bahasa Banjar dalam Jurnal Undas 6(1): 34-46. Banjarbaru: Balai Bahasa Banjarmasin. 